\title{
Organising for power: solidarities and transformation
}

\author{
James Goodman
}

\begin{abstract}
Political and social movements are both empowering and power-seeking: they seek both to mobilize civil society and overwhelm state institutions. As organisations they mobilize collective power, generating solidarities and transforming social structures. As such, political organisations both challenge power and exercise power. This article addresses organizational vehicles for political change in Australia, drawing out limits and possibilities. Three organizational forms are discussed - the political party, the non-government organization (NGO), and the social movement - in terms of their capacity and limits. The social solidarities and social structures that frame political organization are debated, highlighting the impact of political conflicts over ecological change. The article ends with a discussion of the proceeding three articles, drawing out shared themes and implications in terms of the relationships post-Howard, between the Australian state, political parties, NGOs and movements.
\end{abstract}

Organization is the precondition for any sustained challenge to the status quo. For social and political movements, the challenge is to create the structures that can generate and express collective solidarities, producing and channeling collective power. This collective agency of movements is always conditioned by the structural power of capitalism, that in large part reproduces subordination through consent. Capitalism is in this sense a system of self-subjection, albeit buttressed by a coercive apparatus. As Antonio Gramsci argued, capitalist hegemony is the product both of coercive ‘political society’ and consensual ‘civil society’ (Gramsci 1971). Power is thereby exercised through the populace, as well as over it. Organising for power requires recognition of this double-sided character of capitalist society. Challenges to the existing order must be generative, in terms of creating the capacity to transform capitalist social relations from within. They must also be insurrectional, in terms of the capacity to take power over coercive structures.

Any transformation beyond dominant power relations involves asserting a process of de-linking from capitalist values and structures. In this vein, for instance, John Holloway argues that instead of exercising power over others, movements must grasp the power to transform people’s lives beyond commodification (Holloway 2002). In doing so movements must reject the idea of ‘taking' power, he argues, and instead directly dissolve and supersede power structures in everyday life. The social 
movement here centres on civil society, becoming the vehicle for a transformation of social relations and social attitudes. Clearly, though, struggles against capitalist hegemony cannot be confined to civil society. Liberation from social power structures may be the key aspiration, but to be realized movements must, at one moment or another, address political structures: indeed, any violation of capitalist order, whether in the 'everyday' or not, invites coercive intervention.

In Gramscian terms, the transformation of civil society requires the capture of political society. Since the earliest days of capitalism the political structures of accumulation have been the central barrier to social transformation. If anything, these structures are more central today, under late capitalist neo-liberalism. Paradoxically, state power is vital to the process of maintaining, extending and enforcing market rule, and for maintaining social order in the face of resulting volatilities. As David Harvey has argued, the driving dynamic of profit-taking today proceeds primarily through a process of 'accumulation by dispossession', where peoples are literally disinherited and displaced (Harvey 2003). While markets may exert decentred structural power, an 'empire' perhaps, they are embedded in the highly-centred power of sovereign authority (as indeed amply demonstrated by neo-conservativism). Movements must address these political structures: 'organizing for power' is embedded in existing power relations and must seek power over such structures. It necessarily involves creating formations that will be most effective within the prevailing political conditions.

Movement organizations are thus double-sided, in both affirming and transforming social contexts: they are embedded in social relations, but at the same time reach out beyond them, to envisage and construct new possibilities. That is to say, organizing for power cannot happen in the abstract: it has to happen 'on the ground'. The resulting praxis of reflective action, where movements act-on the categories that constitute them, is at the core of social change organizations as reflexive actors that literally remake society. Debates about the organization of collective power very clearly expose these dynamics.

For these various reasons, this Special Issue takes organisation as the first step in its dialogue for alternatives, beyond neo-conservativism. This article introduces the 
section with a survey of organizational concerns within the Australian political context. It begins by conceptualizing the broad field of social change organizations in terms of organizational categories, drawing-out the primary features of the three kinds of organization that are prevalent in the Australian context - the political party, the non-government organization and the social or political movement. Discussion in the second and third sections moves beyond the three-part typology to address the question of social solidarity and social change, asking how emergent social forces and attendant structures influence the logic of organization. In the final section, some specific questions of social change organization in Australia, in the light of Australia's 'extended state' and related social and ecological structures, are addressed, drawing out themes for the ensuing four chapters.

\section{Organisational categories}

Debates about organization centre on organizational form, on a spectrum from most hierarchic to most diffuse. The quintessentially hierarchic organization - the military insurgency - demands absolute obedience on pain of death. The most diffuse organizations may collapse the movement into expressions of subjecthood and individual experience. We may then imagine a continuum from military insurgencies, to religious cults, political parties, political movements, community and nongovernment organisations, social movements, movement networks and affinity groups, extending to the most diffuse attitudinal or affective phenomena, such as what Walgrave and Verhulst call 'emotional movements' (2006), or what McDonald calls 'experience’ movements (2006). Conflicts and disputes over political organization are played-out along this continuum: anti-colonial struggles were fraught with conflicts between insurgent and electoral approaches; the first Communist International divided between between centralism and voluntarism; current movements are patterned by divisions between institutionalism and autonomism (Fominaya 2007; Juris 2008).

The question of which organization is most effective may be understood as a question of 'form' rather than 'content', a tactical rather than a strategic issue. Choice of organizational form may simply hinge on the question of what kind of change is being sought, and what kind of power is being mobilized, and thus what organizational vehicle is required. Within late-capitalist societies discussion of vehicles for social 
change revolves around three main organisational forms - the political party, the NGO and the social movement, each if which has its own limits and possibilities. Clearly if the objective is to deliver votes at a ballot box then forming a political party will be the priority; if the aim is to mobilise informational power we might expect an emphasis on constituting expert status, such as through think-tank NGOs; in contrast, a more participatory social movement model would be needed to deliver popular mobilization and more broad-based social transformation.

As summarised in Table 1, each organisational form targets a specific power source and entails a particular set of assumptions about organizational structure, the meaning of democracy, the nature of the political process and the role of ideology.

Table 1: Parties, NGOs, movements: contrasting themes

\begin{tabular}{|l|l|l|l|l|l|}
\hline & $\begin{array}{l}\text { Source of } \\
\text { power }\end{array}$ & Structure & $\begin{array}{l}\text { Model of } \\
\text { democracy }\end{array}$ & $\begin{array}{l}\text { Political } \\
\text { engagement }\end{array}$ & $\begin{array}{l}\text { Ideological } \\
\text { stance }\end{array}$ \\
\hline Political Party & $\begin{array}{l}\text { Electoral } \\
\text { / legislature }\end{array}$ & Hierarchy & Representative & Partisan & $\begin{array}{l}\text { Holistic, } \\
\text { state-centred }\end{array}$ \\
\hline $\begin{array}{l}\text { Non- } \\
\text { Organisation }\end{array}$ & $\begin{array}{l}\text { Information } \\
\text { / status }\end{array}$ & Elitist & Deliberative & Bipartisan & $\begin{array}{l}\text { NGOist } \\
\text { / extended } \\
\text { state }\end{array}$ \\
\hline $\begin{array}{l}\text { Social } \\
\text { Movement }\end{array}$ & $\begin{array}{l}\text { Popular } \\
\text { mobilisation }\end{array}$ & $\begin{array}{l}\text { Diffuse, } \\
\text { horizontal }\end{array}$ & Participatory & Meta-political & $\begin{array}{l}\text { Sectoralist } \\
\text { / state } \\
\text { antagonist }\end{array}$ \\
\hline
\end{tabular}

Clearly, political parties seek electoral support by presenting manifestos for government. Their electoral powerbase is founded on the representative model of democracy. As a consequence their organizational structure is hierarchic, often with a membership base that in formal terms is required to endorse its leadership. Party leaders then engage in partisan contestation to garner electoral support and ultimately, to exercise governmental power. Not surprisingly, political parties are explicitly statecentric, and generally produce all-encompassing holistic programs for government. 
Non-government organizations, by contrast, rely on informational power and their resulting expert status to gain leverage. Their power is channeled though deliberation rather than representation: accordingly, their structures are more elitist than hierarchic. In the political sphere, NGOs present their priorities as bipartisan, above the fray of party politics. As non-government entities, they express an ideological commitment to non-governmental realms of 'civil society', what some have dubbed 'NGOism'. Beyond this, there is great variety. A small number of NGOs play a key role in social movements, as 'social movement NGOs'; others act as interest groups, for instance as business or professional associations. NGOs may value their autonomy but have an intimate relationship with the state, and inadvertently (or otherwise) operate as semi-state agencies extending state power into wider society.

Social movements have a more diffuse organizational form. Movements can encompass NGOs and political parties, but nonetheless have their own distinct dynamic. In the first instance, the powerbase of a social movement is popular mobilization: rather than creating structures for representation or deliberation, social movements seek to generate participation. This imposes an imperative for relatively flat horizontal structures to maximize popular involvement: informal exclusion or entrenched hierarchy can flourish, but in principle are self-defeating. Rather than forging manifestos, or presenting policy proposals, movements address the underlying operating frameworks of society: they engage in 'meta-politics' rather than more immediate partisan or bipartisan contestations. As Alaine Touraine has insisted, social movements must, by definition, challenge the underlying historicity of society (Touraine 1978). Partly as a consequence, social movements are antagonists of state power, although they can be confined or corralled into specific sectoral concerns.

These categorizations can beg more questions than they answer. If understood as ideal types, they can be used to illuminate political tensions within as well as between organizations, and within collective action. For organizations that straddle the logic of party, NGO, or movement, some of the resulting internal tensions can be particularly difficult, but also creative (one example is the World Social Forum). Beyond the question of categories, we may speculate what kinds of social power are most effective in particular contexts, and thus what kinds of organization are most needed, and how this may change over time. Underlying these debates is the two-way 
relationship between social solidarity and social structure. Social forces generate imperatives for political organization, and enable the solidarities that drive movements. Movements reorder and transform political structures and, in turn, generate new social forces. The schematic typologies of organizational form are embedded in these social dynamics and antagonisms.

\section{Organisation and social solidarity}

When understood as schematic 'form' rather than 'content', organization is interpreted instrumentally, as the medium for the message. The question of organization is thereby reduced to tactical consideration of pros and cons given the prevailing power play. We may then be agnostic, or even complacent, on the question of organization. But organisation is not simply an expression of prevailing power structures. The demands of the movement do not of themselves deliver political traction: it is the embedding of these demands in social and political praxis, through organisational structures, that achieves this. Organisation expresses the power of agency, and is inseparable from the broader strategic process of collective mobilization that defines the content of movement demands. Insofar as organization produces collectivity and solidarity, to re-coin Marshall Macluhan's quip on the media, the medium is indeed the message.

Organisation shapes and expresses movement solidarity, framing movement agendas. Political organisation must therefore reflect movement values: to claim legitimacy for social change, the movement's organizational practices must be in accord with its values. Put simply, movements must 'practice what they preach'. Organisations are not empty shells, they are 'social laboratories' that prefigure aspirations. Movement organisations produce movement agendas, are in this sense the crucible for movement values and solidarities.

Unlike more embedded or systemic solidarities, movement solidarities have to be consciously generated to produce social change, and organization plays a key role in this. The self-conscious process of movement solidarity is generative - it builds political community. As expounded by ‘classical’ sociologists, systemic solidarities may emerge from the relationships between 'traditional' structures and 'modernising' systems, responding to emergent modes of production, divisions of labour, or 
rationalization pressures. These existing forms of solidarity enable social structures to be adapted and reproduced. Self-conscious solidarities, in contrast, arise from deliberate affiliation, and are distinct as they create new forms of identification, association and mobilization. It is these self-consciously constructed affiliations that generate transformative collective action, from within the social formation (Bamyeh 2007). They spring from existing solidarities, but in the process gain an autonomy which transforms and supersedes systemic practices. In this respect, movements are agents of change, rather than symptoms of change: but they are not free agents: paradoxically, they act on society from within society.

The problem for movement solidarities is thus a problem of emergence - how can movements generate the solidarities to produce the required value shift? The answer to this question lies within the dynamic relationships between structural conflicts and movement agency. Given that we live under capitalist social relations, it is capitalism's structural conflicts that set the stage for movement agency: understood historically, those conflicts change over time, generating contrasting modes of movement and organisation.

\section{Organisation and social structure}

Specific forms of capitalism have very different social effects, and set the framework for different forms of movement organization. At the same time, movements act-on and transform capitalist relations, framing the conditions of emergence for succeeding forms of accumulation. Following the Dutch political economist, Kees van der Pijl, we can argue that industrial accumulation channeled movements into class-based solidarities, particularly through trade unions (Van Der Pijl 1998). The revolt against labourism and social democracy in the later decades of the Twentieth Century, from the so-called 'new social movements', then prefigures more 'flexible' intensive modes of informational capitalism and neo-liberal globalism. The crises of social and ecological 'exhaustion' that arise under intensive accumulation now see the emergence of survival-centred movements for the social and ecological 'commons', movements that construct and assert the existence of common normative foundations for survival. Such movements force new mutations in accumulation, although still in formation, as perhaps most clearly (and astoundingly) played out in the emergence global carbon trading, set to become the world's largest commodity market. 
The new dispensation raises qualitatively different problems, and possibilities. Industrial accumulation centres on the contradiction between capital and labour, and creates a 'realisation problem', of how to sell more commodities while constraining the income of workers. Intensive accumulation, by contrast, centres on a capitalnature contradiction, and presents the problem of how to manufacture more products with less ecological impact. As James O’Connor argues, this 'second contradiction' is now dominant, forcing new eco-centric frameworks into view (O’Connor 1998). As the conflict between capital and nature comes to pattern society as a whole, all social issues become unavoidably ecological issues. The point is made most clear by the example of climate change, where all possibilities of social development and social justice, in all contexts worldwide, hinge on the capacity to reduce greenhouse gas emissions. Notwithstanding a continued faith in 'climate-proofed' development, if certain not-so-far-off tipping points are breached we have to expect nothing less than planetary developmental collapse. As Van der Pijl argues, the social is now unalterably subsumed into the ecological. Possibilities for survival under this 'intensive' capitalism hinge on the movement's capacity to generate solidarities and to construct and enact the required values.

Global interconnectedness arising from ecological crisis creates new imperatives for reflexivity, which create new forms of ecological solidarity. Just as industrial capitalism created new sets of interchangeable roles, what Ernest Gellner called the 'musical chairs society', so today we see 'intensive' or informational capitalism forcing the emergence of new solidarities. Where Gellner saw nationalism as providing the industrial identity-fix, so today various observers, Ulrich Beck and Anthony Giddens among them, argue that modes of precautionary self-regulation emerge in response to increased exposure to global flows and ecological risk (see Beck, Giddens and Lash 1994). Reflexive modernity, in this reading, forces peoples to live with regard to their 'side-effects', and in the process, by necessity, solidarities become less fixed to territory and much more fluid and contingent.

As the principal carrier of collective reflection and action, the movement moves to the core of reflexive modernity, generating the values and affiliations that underpin solidarities. In the process, as Mohamed Bamyeh argues, the emergent movements 
recombine existing 'primary values' - whether material, universal, spiritual, humanist or emancipatory - to produce the new solidarities and organizations capable of enacting them (2007). For some, the imperative for fluid affiliations supersedes solidarity. Kevin McDonald for instance argues that solidarity requires a single focus for affiliation, and cannot express the capacity to move across identifications that has emerged at the core of movement politics. He argues the imperative for 'fluidarity', not solidarity, centres the movement on affinity and experience. It dictates diffuse movement organization with loose horizontally-aligned networks that allow for convergence of shared values rather than coordination or control. Here, the very notion of a movement that expresses a singular 'collective identity' is redundant: identification is meshed across a range of affiliations and is enacted not so much through movement organizations as through embodied and affective experience in movement actions, what McDonald calls the 'public experience of self' (McDonald 2002; 2006).

To a significant degree, though, these modes of political mobilization are not new. As Calhoun notes, movements have historically combined affective or expressive forms of mobilization with cognitive and instrumental politics: movements of the early Nineteenth Century in Britain, such as the Chartists, were no less identity-centred and expressive than current-day movements (Calhoun 2000). There is change in these continuities though, not least as capitalism's freedoms and society's aspirations conflict and react to produce new dispensations. With 'neo-capitalism' breaking the constraints of accumulation in a new wave of intensive commodification, counterscripts in the form of social movement critiques force new agendas into view. In the search for legitimation we see a 'new spirit of capitalism' emergent, which creates new ways to justify the prevailing globalised and networked order. For Boltanski Abd Chiapello these new 'mechanisms of justice' are dispersed but city-centred, where agglomerations of social agency can gain traction (Boltanski and Chiapello 2005: 519).

Similar formulations are advanced in Hardt and Negri's concept of 'Multitude', which (paradoxically) agglomerates mass individual reflexivity into revolutionary agency. The Multitude, they argue, is a 'distributed network', where 'each struggle remains singular and tied to its local conditions but at the same time is immersed in the 
common web', where the extension of a common field strengthens rather than undermines the singularities of its participants (Hardt and Negri 2004: 217). As with the universalist 'empire' that it challenges, the Multitude has no centre: instead it is diffused across social life, taking root wherever peoples assert self-rule and wrest control of their own means of social reproduction. There is no overarching metaframe for political change - only the liberation of social time from capital accumulation. The new model is presented as a synthesis of unity and difference, combining the commonalities expressed in centralised movement hierarchies with the affective engagement of autonomous difference politics; in doing so, 'the new network model of the multitude displaces both these options’ (2004: 217).

These various treatments posit a dichotomy between relatively fixed political categorizations associated with modern class and state hierarchies, with more fluid formations prevalent in late modernity. The age of global reflexivity is said to be the age of contingency, and therefore, of agency. Movement organizations have little to do in these scenarios: they are submerged by the social impulses said to overwhelm structures of rule. The result may be, as Frank Furedi has argued, a collapse into episodic expressions of public outrage, a personalization of protest where movements become an outlet for individual expression (Furedi 2004a; 2004b). Such 'emotional movements' may themselves be aligned with rather than against authorities, in generating as impulse to reaction rather than transformation (Walgrave and Verhulst 2006). Indeed, periods of rapid change have historically offered opportunities for forces of reaction as well as forces for transformation. As Karl Polanyi highlighted, the Great Depression of the 1930s laid the basis for a socialization process that gave rise to fascist as well as social democratic forces (Polanyi 1944). These histories may now have direct lessons for the present as we enter what in 2009 the IMF began calling the ‘Great Recession’ (Strauss-Kahn 2009). Movements are not automatically driven by systemic structures to progressive, transformative agendas: in periods of capitalist crisis, ideology and political strategy become if anything more important.

More fundamentally, though, the very idea of distributed networks and unorganised fluidarity is in direct conflict with the notion that we are living under ecological crisis. Instead of disaggregating movement identities, the advancing crisis of global warming is undoubtedly more totalizing than any of the preceding crises of modernity. In its 
wake, the crisis literally subsumes all other political agendas. Indeed, there is nothing contingent about global warming. In this respect, we can predict, and perhaps witness, a growing global alignment of movements under the singularity of climate crisis. That is not to say there is a uniform response: there are multiple ways of addressing the crisis, and multiple possibilities for social change arising from it. Significantly, though, just as class has done in the past, climate is likely to, over time, emerge as a central fulcrum on which solidarities emerge and converge.

Emergent climate action movements are already constructing deep roots. In the first instance they build on a deep-seated affective crisis - an epistemological crisis perhaps. Where Touraine addressed the counter-cultures of the 1960s and 70s in confrontation with the conformity of 'programmed' societies, the current climate action movements address a societal contradiction that literally pits capital against life itself. In this context, given the scale and imminence of the problem, a deeply transformative and affective response is to be expected. As with movements of the past, though, such responses rest on a shared cognitive interpretation, of the causes and effects of climate change. Global warming thereby generates a shared and now globalised political frame, albeit inflected with different perspectives. The effects of that reframing can be profound: on the question of democracy for instance, the crisis of survival produces a new demos that extends across generations, and across species. The priorities of the present are now weighed against the developmental survival of future generations and the intrinsic responsibility to avert species extinction. Addressing climate change thus means reinventing democracy, embedding it in new ethical frameworks for existence.

If global warming creates a new global meta-frame for movements, it also forces a direct confrontation with dominant paradigms of growth and accumulation. Given there is no possibility of adaptation to climate change, it must be directly mitigated 'at source'. Such mitigation, to be effective, forces us beyond consumer capitalism: even the most optimistic scenarios for reducing carbon intensity signal the need to curtail global growth rates ( $\mathrm{Li}$ 2008). To use the categories developed by Boaventura de Sousa Santos, there is no 'sub-paradigmatic' pathway: only a paradigmatic transition can address the crisis (Sousa Santos 1995). Unlike the social democrats who a century ago sought 'evolutionary socialism' (see Bernstein 1961), there is no scope 
for a long march through the institutions. While the welfare state could to a degree socialize class division, offering an evolutionary pathway for socialists, it is increasingly difficult to lend credence to evolutionary ecologism. Even if that were possible, time has run out. Indeed, the abject failure of existing institutional orientations, beholden in the first and last instance to vested interests, is already forcing new forms of ecological transformation, indeed, revolution, onto the agenda (Goodman 2009). We are faced with a profound clash of paradigms, and one that is irresistible, driven by 'nature’s revenge' on capitalism, as Engels put it (see Anderson 2006). That 'revenge' cannot be managed or displaced, and as it intensifies unabated it is giving new traction to movements, generating new visions and possibilities for revolutionary change.

\section{Social and ecological change in Australia's 'extended state'}

New movement organizations are built to challenge new configurations of power and exploit new possibilities of mobilisation. In this sense, movement organisations could be understood more as processes than institutions: they are relational, constituted in the dynamics of contestation. With this in mind, how can we approach the question of organising power in Australia, in the post-Howard era? As noted, public political activity in Australia is channeled into parties, NGOs and movements. Most political players in the Australian context either fit closely into one or other category, or explicitly sit across two of the categories. As outlined in Lee Rhiannon's chapter for this Section, environmental organizations are represented across all three categories.

The relationship between the resulting organisational imperatives can be crucial in shaping ecological outcomes. Where, for instance, movement and party are in alignment, there can be considerable rewards; alternatively, NGO and movement can come into contradiction, with, for instance, NGOs actively displacing environment movements. In different circumstances, tendencies to expressive movement actions can be complemented by NGO discursive interventions. More centrally, as Lee Rhiannon argues, links between the political party and social movements are an absolute imperative if Green party, indeed any progressive party, is to withstand pressures to electoral bloc-formation. For political parties dedicated to transformative social change - whether revolutionary or not - linkages to social movements are not an option, they are a necessity. 
Organisations themselves change over time, across organisational categories. A political movement may for instance create a political party that then takes on a life of its own, autonomous of the movement. Social-democratic parties, for instance, many of them established by trade unions, have often sought to sever organizational links with affiliated trade unions, enabling a shift to a more social-liberal party orientation. The divorce between trade unions and 'their' party or government can be initiated by either side: in NSW for instance in 2007, it was the trade union movement, represented through Unions NSW, that led a broad-based labour movement mobilization against the NSW Labor Government's proposal to privatize electricity. Demonstrating the possibilities of relatively autonomous union mobilization, in this instance in collaboration with environmental organizations, along with overwhelming support from the 2008 NSW ALP conference, the campaign was remarkably successful. With all ALP MPs voting in defiance of Labor conference, a sharp divide was opened up between party and government, dissolving the assumption of 'policy consent' that dated back to the 1940's (Kelly 2008). An internal coup followed, the Party installed a new Premier, privatization of electricity generation and distribution was shelved, with privatisaton of electricity retail, and provision for new private power stations, quietly brought forward (Kruse 2008).

In other contexts, the organization itself may move across categories. There are many examples of movement organizations becoming institutionalized, to become NGOs: this is especially prevalent in the Australian context given the historical intermeshing of state power and civil society organization. Federal and State departments are peculiarly 'extended' into civil society, through various contracting-out and other funding mechanisms, creating grey-zones of semi-stateness where NGOs operate as informal extensions of state power. Australia's extended state operates across multiple fields, transforming feminist, indigenous, migrant, lesbian and gay, welfare, and other movement organisations into NGO service providers dependent on government funding. As outlined in Sarah Madison's chapter for this Section, NGOs in Australia, as a consequence, face a series of dilemmas and imperatives in maintaining their autonomy. 
There are direct political consequences: given their privileged relationship with government, NGOs, may, advertently or otherwise, find themselves marginalizing and policing movements. Relatively disaggregated environmental NGOs, for instance, actively compete with one another and with movements to capture political space: NGOs often deliberately position themselves as the 'reasonable' voice on an issue, to capture the middle ground in a policy debate, and in the process de-fang environmental movements that may compete for media exposure or membership. An important illustration of this process is the debate over climate change, where a number of environmental NGOs have deliberately taken positions that are known to be unsustainable, simply to gain an entré into the public debate. In such circumstances the NGO operates as a 'minesweeper' for the government, clearing the pathway of ideological obstacles, enabling the maintenance of a clearly non-viable status quo.

Another important aspect of policing, and of the extended state, is the imposition of specific government regulations that delimit political categories, one from the other. Such regulations can directly shape the actions of potential players: in the case of the very large charitable sector for instance, there are very clear injunctions against what are deemed by the Australian Tax Office to be unacceptable 'political activities'. As Sarah Madison outlines in their chapter for this Section, these regulations have a powerful 'chilling effect' as charities self-police in order to retain their financial status. Australia does not have a strong tradition of sustained autonomous movement organization based on membership income: in most sectors, except the trade union sector and some cases in human rights advocacy and development assistance, organizations either directly rely on government funds or else are dependent on charitable status to gain access to charitable foundations and tax-deductible donations.

Policing is especially pervasive in the trade union sector, where employers have the right to sue unions and penalize individual employees if they take industrial action that is 'unprotected'. Unions can take protected industrial action during periods of collective bargaining, but only if they are registered: there is no right to strike for unregistered unions. The industrial muscle of the Australian labour movement is thereby contained within a highly restricted field of protected industrial activity. In the context of 'enterprise'-based collective bargaining, unions have often become defined as interest groups, primarily acting to provide a service for their membership 
rather than as part of a movement that seeks to transform broader social relations. Trade unions have sought to counteract this tendency through internal transformation on the industrial front into member-based ‘organising' unions rather than expertbased 'servicing' unions. Externally they have sought broader reorientations, away from close reliance on a social partnership with government, to new forms of community and social movement unionism (as for instance outlined in Amanda Tattersall's article in Section 1), and to modes of political unionism, such as in the landmark 'Your Rights at Work' campaign (as discussed by Sally McManus, also in Section 1).

The effects of political regulation, though, are double-sided. The act of policing itself betrays a vulnerability, as the resort to coercion signals a failure of legitimation. The spectacle of coercive power, displayed for political effect, demonstrates the extent to which an issue has been contested and politicized. This, in itself, can be a key achievement of social movements, in forcing public attention and deliberation. As Sergio Fiedler highlights in his chapter for this Section, social movements most clearly deploy their autonomous power when they engage in mass civil disobedience, forcing the authorities to act. Where the response is coercive, the movement may be no less effective. The process of provoking and confronting coercion in the name of collective goals can have a powerful resonance, and historically has been central to the extension of political rights, of social provision, and of cultural recognition. The two great 'anti-systemic' social movements of the last two centuries that were identified by Immanuel Wallerstein - the movement for social democracy and the movement against colonialism - depended on such approaches (Wallerstein 2003). Fiedler argues that current globalizing forces now position refugees at the cuttingedge of political subjectivity, in forging and claiming new forms of agency. The extension of political community across borders, whether through migration or otherwise, has been a central question for social movements, although one that has often been deferred. That deferral now unravels in the face of cross-national flows: we now see the same phenomenon across multiple sites, including, as emphasised here, the issue of ecological survival. In these contexts where the meta-political framework, society's historicity, comes under challenge, the social movement organisation becomes most necessary, and effective. 


\section{Conclusion}

Organisation sits at the centre of social and political change. Movement organisations transform latent potential into a social and political force capable of transformative action. Social change organisations thereby take on a constitutive role in terms of selfconsciously crystalising movement solidarities. Organisational questions are thus both tactical and strategic questions, entailing the creation of alternative agendas as well as a means of enacting them. As argued here, such movements paradoxically act-on society from within: by acting on society they confront immediate structures, politicizing and delegitimising power holders; by acting within society they create the power to transform social relations, making society anew. In the current period, where we sit on the cusp of a new social order forced into place by ecological exhaustion and climate change, we can expect movement organizations to move to centre stage. As existing institutions fail in the face of mounting crisis, the creative praxis of movement organisations offers us the best foundation for the revolutionary transformations that are so urgently required.

\section{Bibliography}

Bamyeh, M. (2000) The Ends of Globalization, University of Minnesota Press: Minneapolis.

Beck, U., Giddens, A. and Lash, S. (1994) Reflexive Modernization: Politics, Tradition and Aesthetics in the Modern Social Order, Stanford University Press: Palo Alto, C.A..

Bernstein, E. (1961) Evolutionary Socialism: A Criticism and Affirmation, Random House: New York.

Boltanski, L. and Chiapello, E. (2005) The New Spirit of Capitalism, Verso: London.

Calhoun, C. (2000) 'New social movements of the early nineteenth century', in Nash, K. Political Sociology reader, Blackwell, Cambridge.

Durkheim, E. (1984) [1895]. The Division of Labor in Society, translated by W. D. Halls, Free Press: New York.

Fominaya, C. (2007) Autonomous Movements and the Institutional Left: Two Approaches in Tension in Madrid's Anti-globalization Network, South European Society and Politics, 12, 3, 335-58.

Furedi, F. (2004a) 'Politics of the lonely crowd: protest movements get personal', Spiked, 9 March, www.spiked-online.com/Articles/0000000CA449.htm, accessed 20 January 2009.

Furedi, F. (2004b) Where Have All the Intellectuals Gone?: Confronting 21st Century Philistinism, Continuum: New York.

Goodman, J. (2009) From global justice to climate justice? Justice ecologism in an era of global warming, New Political Science, Special Issue on the Changing Face of Political Ideologies in the Global Age, 31, 4, forthcoming.

Gramsci, A. (1971) Selections from prison notebooks, Lawrence and Wishart: London. 
Hardt, M. and Negri, A, (2004) Multitude: war and democracy in an age of Empire, Penguin: New York.

Harvey, D, (2003) The new imperialism, Oxford University Press, Oxford.

Holloway,J. (2002) Change the world without taking power, Pluto Press, London.

Li, Minqi (2008) Climate Change, Limits to Growth, and the Imperative for Socialism, Monthly Review, July-August.

Juris, J. ( 2008) Networking Futures: The Movements Against Corporate Globalization, Duke University Press: US.

Kelly, P. (2008) 'NSW is in a state of dysfunction', The Australian, 15 November.

Kruse, B. (2008) 'Premier Approves the Sale of Energy Retailers', United Services Union Press Release: Sydney.

Macdonald, K. (2002) From solidarity to fluidarity social movements beyond 'collective identity' - the case of globalization conflicts, Social Movement Studies, 1, 2.

McDonald, K. (2006) Global movements: action and culture, Blackwell: Oxford.

O'Connor, J. (1998) Natural causes: essays in ecological marxism, New York: Guilford Press.

Polanyi, K. (1944) The Great Transformation: The Political and Economic Origins of Our Time, Beacon Press: Boston.

Sousa-Santos, B. de (1995) Toward a new common sense: Law, Science and Politics in the Paradigmatic Transition, Routledge, New York.

Strauss-Kahn, D. 'Successful Partnerships for Africa's Growth Challenge,' speech in Dar es Salaam, IMF: Washington.

Touraine, A. (1978) The voice and the eye, Cambridge University Press: Cambridge

Van der Pijl, K. (1998) Transnational classes and international relations, Routledge: London.

Walgrave, S. and Verhulst, J. 2006 'Towards "new emotional movements"? A comparative exploration into a specific movement type', Social Movement Studies 5(3): 275-304.

Wallerstein, I. (2003) The decline of American power, The New Press: New York. 